\title{
Promoting Social Entrepreneurship: Harnessing Experiential Learning With Technology Transfer To Create Knowledge Based Opportunities
}

John Lipinski, Middle Tennessee State University, USA

Donald L. Lester, Middle Tennessee State University, USA

Jeananne Nicholls, Slippery Rock University, USA

\begin{abstract}
Technology Transfer has grown in importance as more university developed technology is reaching commercialization to the benefit of numerous stakeholders. However, $75 \%$ of university patents are never licensed for development. Often cited is the need for a product that will rapidly generate a positive cash flow. Universities have an additional opportunity. They can work to link experiential learning courses with their technology portfolios to conduct activities like prototyping, market research, and market testing and work with social entrepreneurs to help launch technologies that may prove to be both beneficial to society and to a commercial operation while educating students.
\end{abstract}

Keywords: Social Entrepreneurship; Technology Transfer; Experiential Learning; Sustainable Strategic Management

\section{INTRODUCTION}<smiles>[C]1C=CCCC1</smiles>
ocial entrepreneurship, experiential learning (EXL), and technology transfer are three leading trends that have been studied widely in the past two decades. Each has led to changes in the traditional university model and to new opportunities. In this paper we build a model positing that by effectively combining these three areas, universities will find numerous opportunities that, in addition to producing better educated and trained university students, could 1) better utilize university resources, 2) provide new goods and services to underserved populations, and 3) foster new companies and service organizations. The combination of these three areas can help to alleviate many of the primary bottlenecks in getting technology to market: missed opportunities in research, design, development, and deployment.

At his inauguration, the new President of the Massachusetts Institute of Technology, L. Rafael Reif addressed the challenges of university research and the potential contribution to society. Reif stated "Society continues to need what the residential research university does better than any other institution." He cited universities' ability to "incubate brilliant young talent, and create the new knowledge and innovation that fuel our society." He further added that "the pressures of cost and the potential of new technologies are presenting all of us in higher education with a historic opportunity: the opportunity to better serve society by reinventing what we do and how we do it. It is an opportunity we must seize." (Chandler, 2012)

The majority of university-generated innovations fail to leave the academy. One reason is lack of institutional support, a critical component of technology transfer, particularly for social entrepreneurship technological innovations. A discussion of the literature and the three constructs of this integrative approach are presented. 


\section{LITERATURE REVIEW}

\section{Social Entrepreneurship}

The construct of social entrepreneurship has survived multiple attempts at definition, including the effort to create social value (Peredo \& McClain, 2006), the pursuit of social change (Roberts \& Woods, 2005), attempting change in the social sector and willing to assume risks to accomplish that change (Dees, Emerson, \& Economy, 2001), vision driven problem solving groups (Bornstein, 2004), and non-profit organizations who bring about social transformation by altering the public perception of social issues (Alvord, Brown, \& Letts, 2004). Employing innovation as a unit of analysis, Dart (2004: p. 13) defined social entrepreneurship as "an encompassing set of strategic responses to many of the varieties of environmental turbulence and situational challenges that nonprofit organizations face." Bloom and Dees (2008) take defining social entrepreneurship a step farther when they aver that social entrepreneurs are trying to solve the underlying problems, not just relieve a problem's symptoms.

The early origins of social entrepreneurship emerged from two different sources with two different meanings. First, the term was utilized to emphasize income generation by not-for-profit ventures (Light, 2005). Second, the term referred specifically to the finding and solving of societal problems (Ashoka, 2006). Perhaps Mair and Marti (2006) integrated these two ideas most successfully when they defined social entrepreneurship as the innovative use of resources to explore and exploit opportunities that meet a social need in a sustainable manner. The individual most credited with establishing the first theoretical clarification of social entrepreneurship was Dees (1998) who outlined three primary components of the construct: Recognition and pursuit of new opportunities to create social value, continuous engagement in innovation and modification, and bold action taken without accepting perceived extant resources. It then follows that social entrepreneurs are mission driven, addressing social problems through innovativeness and risk-taking (Sullivan Mort, Weerawardena, \& Carnegie, 2003).

A parsimonious yet comprehensive definition of a social entrepreneur was put forth by Vega \& Kidwell (2007: p. 16) who said the social entrepreneur is "an individual who addresses a serious societal problem with innovative ideas and approaches that have not been tried successfully by private, public, or nonprofit sector entities." They go on to recognize that addressing societal problems cannot be undertaken without assuming an element of risk, or put another way without capital resources. The distinction to be made between traditional entrepreneurs and social entrepreneurs centers on the expected return. Being market driven, traditional entrepreneurs seek profit through the pursuit of opportunities for new goods and/or services through the formation of new relationships (Eckhardt \& Shane, 2003). The ultimate goal is a sustainable return on investment. Social entrepreneurs, however, seek to correct a societal ill, with returns ultimately benefitting society (Hibbert, Hogg \& Quinn, 2005).

Paralleling the field of entrepreneurship itself (Vega \& Kidwell, 2007), social entrepreneurship has yet to reach an acceptable critical mass with relationship to theory development and wide-spread acceptance. However, it is increasingly being differentiated from private, public, and nonprofit sectors through the elements of innovation and risk. Based on the volumes of journal cites and other related publications, the field is growing in both practice and research.

As previous researchers have noted, social entrepreneurs may be found in at least three different sectors of the economic environment. These sectors include the for-profit arena where an innovative activity with a social purpose is actually a commercial venture (Dees \& Anderson, 2003), the nonprofit arena, and a hybrid sector that mixes the for-profit and nonprofit approaches (Dees, 1998; Austin, Stevenson, Wei-Skillern, 2006). In the nonprofit sector a clear dilemma presents itself. If the organization is mission driven (Dees, Emerson, \& Economy, 2001) to alleviate the oppression of some social ill, or at least somehow lessen its effect, accomplishing this mission successfully is many times the only goal of consequence for the social entrepreneur, what some have referred to as a SROI, or a social return on investment (Vega \& Kidwell, 2007). However, there is also tension that results from the need of the entity to provide some kind of return to its backers (Galpin \& Bell, 2010), or a tangible ROI. 


\section{Technology Transfer}

Roessner (2000) defines the concept of technology transfer as the movement of know-how, technical knowledge, or technology from one organizational setting to another. In the United States, the concept of technology transfer took on significant importance in 1980 with the passing of the Bayh-Dole act. The Bayh-Dole act created incentives for universities having government-funded research to patent technologies developed on their campuses and actively seek licensing opportunities to commercialize their intellectual property. In the years quickly following 1980, the US congress passed eight major policy initiatives dealing with technology transfer and the means of promoting it while similar trends have occurred in other nations (Lederman, 1994; Fujisue, 1998; Licht \& Nerlinger 1998). European countries are also increasing the political pressure on their universities to raise research funding from industry and contribute actively to industrial innovation (Arnold et. al., 2006). While changing the model at many universities, such activities have yielded a number of benefits.

As early as 1996, the Association of University Technology Managers (AUTM) reported that technology transfer programs are integral to an academic institution's mission: education, research and public service. (AUTM 1996) The Bayh-Dole act reduced federal funding for research activities, but this had the effect of incentivizing universities to seek alternative funding streams, largely from private industry (Lipinski et. al. 2008). While obtaining funding via licensing agreements with private industry has not been without controversy, with such concerns being raised even prior to the enactment of Bayh-Dole (Mowery et. al. 2004), clearly a number of successful technologies and new companies have been nurtured via the university technology transfer process. For example, Carnegie Mellon University, in Pittsburgh, PA reports that $34 \%$ of the companies created in the state of Pennsylvania in the past five years (2007-2012) are based on university technologies (http://www.cmu.edu/startups accessed 8/26/2012).

There have been differing levels of success by universities and their technology transfer efforts (Phan \& Siegel, 2006; Porter, 2003; Porter \& Stern, 2001; Etzokowitz et. al., 1998). One issue is that university technology transfer programs often do not produce immediate results for a region. However, many programs result in a long term impact on regional growth (Florida \& Cohen, 1999). Some geographic regions are more successful at capturing the economic benefits of new technologies and adapting to changes in market demand (Furman, Porter \& Stern, 2002; Porter, 2003; Niosi \& Banik, 2005). More importantly, Varga (2000) found that the primary factor influencing innovation activity is the presence of a university. When a university engages with a community, new ideas spur new opportunities.

Universities are primarily motivated to collaborate with industry by the need to raise additional resources required to fund research and other university activities (Cohen et. al. 1998). This requirement becomes mutually beneficial, having positive effects on academic research and private sector innovative activity (Guldbrandsen \& Smeby, 2005). While examples abound of the positive effects of technology transfer, one case in point demonstrates this well. In the early 1980s, researchers at the University of California, Davis, under the direction of Dr. Raymond Rodriguez, a molecular biologist, began working on improving the quality of rice as a means of trying to alleviate the world-wide hunger issues (Lawrence, 2008). A grant from the state government was instrumental in facilitating this research. Many research directions came from this early work, and eventually, in 1993, Dr. Rodriguez, with help from an angel investor, formed a company named Ventria to pursue possible commercial applications of his team's findings. Several of his former students were involved in the enterprise.

With the assistance of some professional managers added to the firm, particularly Scott Deeter as CEO, the list of ideas was narrowed to one or two that would be both a benefit to society and potentially sustainable in terms of profitability. The result was the incorporation of two compounds, lactoferrin and lysozyme, that are naturally found in human breast milk. Both were considered natural antibiotics, and the hope was that their production on a large scale through rice would help alleviate the problem of children's diarrhea, estimated to be approximately 4 billion episodes a year by the World Health Organization (Lawrence, 2008). After much wrangling with the California authorities and rice growers, Ventria eventually landed in Kansas, with a research center in Colorado, and has become a viable entity fighting a societal ill while serving stakeholders and university research. 
However, money is a key determinant in whether or not university technology is licensed and developed. Technology entrepreneurs are under enormous pressures from investors, particularly at the early stages to quickly produce a product and generate cash-flow. Such pressure on entrepreneurs has been shown to detrimentally influence decision cycles, especially major strategic decisions related to re influenced by investment (Perlow et. al., 2002). As such, only about $25 \%$ of university patents are never licensed (Kato \& Stevens, 2012). The remaining $75 \%$ sit on the shelf.

\section{Experiential Learning}

Recent efforts to improve higher education have focused on improving the learning process in education through the application of research from the new science of learning. Of particular interest is the stream of experiential learning (Kolb \& Kolb, 2005). The Association for Experiential Education (1994, p.1) defines experiential education as a process through which a learner constructs knowledge, value, and skill from direct experience. The concept draws on the work of numerous prominent $20^{\text {th }}$ century scholars who gave experience a central role in their theories of human learning and development - notably John Dewey, Kurt Lewin, Jean Piaget, William James, Carl Jung, Paulo Freire, Carl Rogers, and others to develop a holistic model of the experiential learning process and a multilinear model of adult development (Kolb, 1984). Based on his book Democracy and Education (1916), Dewey is often cited as the originator of experiential learning. His belief was that education was not simply the transmission of facts but the education of the entire person, and he viewed the educational experience as involving the teacher and learner engaged in purposive experience (Dewey, 1938).

Experiential learning is a holistic philosophy where carefully chosen experiences, supported by critical analysis and synthesis, are structured to require the learner to take initiative, make decisions, and be accountable for the results. This is done through actively posing questions, investigating, experimenting, being curious, solving problems, assuming responsibility, being creative, constructing meaning, and integrating previously developed knowledge (Itin, 1999). The teacher is responsible for presenting opportunities for experiences, helping students utilize these experiences, establishing the learning environment, placing boundaries on the learning objectives, sharing necessary information, and facilitating learning. The learner is challenged to move beyond what is known. (Chapman, McPhee \& Proudman, 1995; Itin 1997; Kolb 1984).

\section{THE EFFECTS OF EXPERIENTIAL LEARNING ON ENTREPRENEURSHIP}

Learning is a cognitive and social process of knowledge acquisition (Gemmell 2011). Researchers (Armstrong \& Mahmud, 2008; Chandler \& Lyon 2009; Baum \& Bird 2010; Gemmell et al. 2011) have begun exploring how the knowledge acquisition process has helped entrepreneurs generate ideas. Cognitive flexibility is one of the keys to creativity and innovation. Entrenchment inhibits an individual's ability to innovate (Pinard \& Allio 2005; Kolb \& Kolb 2005; Dane 2010). Spiro et. al (2003) explains how the use of knowledge in real-world settings (such as experiential learning) adds to cognitive flexibility. In addition to simply training potential entrepreneurs with "know how" courses, a study by Clark, Labuzetta, Lawrence, Sahakian and Vyakarnum (2008) suggests that teaching risk tolerance may also be desirable and encourage more entrepreneurial activity. This can be conducted through experiential learning.

Politis (2005) explains how entrepreneurs learn experientially through two different transformational modes, first by exploiting existing knowledge through testing actions similar to earlier experiences and second by exploring entirely new actions. Holcomb et. al (2009) further demonstrates that entrepreneurs gain tacit knowledge through both experience and observing the actions and results achieved by others. By exposing students to realworld experiential learning projects and discussing their experiences with groups of other similarly engaged students, they will be exposed to both modes of education.

The value of experience cannot be overstated. The inability of new and small firms to build sustainable business models is well documented, as about half of all start-ups last between five and seven years (Kuratko \& Hodgetts, 2001). However, $82 \%$ of businesses that lasted at least twenty years were still in business according to Birch, Gundersen, Haggerty, and Parsons (1999). To promote the long-term success of business enterprises, researchers in the last two decades have emphasized a sub-discipline of strategy referred to as sustainable strategic 
management (SSM) (Parnell, 2008). A working definition of SSM involves the strategies and related processes associated with superior performance over time from both a market and environmental perspective (Carraher, Buckley, \& Carraher, 2008). One factor contributing to the failure of businesses has clearly been environmental turbulence (Stead \& Stead, 2008). Many small business founders, as well as seasoned corporate executives, have found increasing environmental turbulence to be an overwhelming issue. While early strategic researchers focused on the internal importance of strategy formulation and implementation, SSM stresses the need for firms to understand the importance of, and interrelationships with, the people and environments in which the firm operates (Stead \& Stead, 2008). An emphasis on strategic planning (Steiner, 1979) is one tool to assist firms, particularly new ones, in overcoming the trials of environmental turbulence.

Many technologies fail to be developed due to market failures. This is especially true in a social entrepreneurial context where technologies designed to impact the poor are perceived to be plagued by low financial returns on investment and high risk. However, numerous researchers have worked to counter this notion. Prahalad and Hammond (2002) discuss the notion of serving the world's poor profitably and observe that, in reality, consumers at the bottom of the pyramid pay much higher prices for most things than middle-class consumers. Therefore, there is a real opportunity for companies with economies of scale and efficient supply chains to capture market share by offering higher quality goods at lower prices while maintaining attractive margins. No enterprise is immune from the threat of failure, and adoption of the SSM philosophy is critical to the long-term sustainability of any organization operating in a free enterprise system, including nongovernmental organizations (NGOs), opportunity seeking firms, and technology transfer based start-ups. At issue, in particular, is the ability to meet the needs of both internal and external stakeholders, including consumers, employees, government regulators, and investors (Stead \& Stead, 2008).

Experiential learning and technology transfer can help to eliminate the market failure problem. Students, while learning the theory and application of their craft, can help to tackle research, design, development, and deployment problems. This is low risk for universities, because even if the students' efforts fail, the primary goal of learning has still been achieved.

\section{Two EXL Examples: The Small Business Institute and the Invention Evaluation Service}

Long before the concept of experiential learning became popular, or even required, the Small Business Institute (SBI) was promoting field-based student consulting. The SBI also promotes and supports research in entrepreneurship and small business management, offering conferences, workshops and seminars for both educators and practitioners. The focus of the SBI, however, has always been on rigorous, formatted student consulting projects for small businesses and entrepreneurial start-ups.

Both graduate and undergraduate students participate, under the supervision of experienced faculty, in business consulting, technical assistance, or feasibility studies for business clients. The clients are typically charged a very low fee or none for the projects, and only a few requirements are necessary. To qualify for a referral program, a client must:

- $\quad$ Have a project that would fit in an academic period (typically a semester);

- $\quad$ Be willing to meet with the students and provide all needed information (confidentiality statements are utilized);

- $\quad$ And, meet any requirements needed by the specific SBI program that the client is being referred to.

Normally the SBI project is the centerpiece of a stand-alone course. The SBI provides a text (Cook \& Belliveau, 2008) for the course that addresses each step of the student consulting project. The primary advantage of any experiential learning process is that students are put into an actual situation (in this case, a business problem) that requires a specific plan of action to be prepared within a limited time frame. Other benefits to students of the course include the preparation of an industry analysis, working together as a team, preparing and executing a letter of engagement, preparing a final report, and presenting that report to the business owner/operator(s). Students are also required to create and maintain a journal throughout the duration of the project. Specific learning outcomes include: 
- $\quad$ The steps necessary to develop and facilitate a project plan;

- $\quad$ The group collaborative process in decision making and project performance;

- $\quad$ And, how to recognize and conceptualize a complex issue into a clearly written summary.

While EXL programs have a much wider scope, SBI student consulting projects represent an example of what a university could do if EXL programs were comprehensively planned to facilitate tech transfer through the utilization of student projects. EXL student teams could work across disciplines to advance technological innovations or build implementable models while business students could work in tandem, providing feasibility analysis and business consulting. Although not every university has a comprehensive business school, most offer at least limited degree programs or course offerings. One added long-term benefit to a planned EXL program is that many SBI consulting projects lead to students opening their own businesses. Since EXL programs focus on forprofit and not-for-profit projects, those worthy of advancing past the testing stage need full-time owner/operators to be successful. Entrepreneurially minded students might be willing to take up the cause and carry a new idea forward, hopefully becoming a thriving enterprise.

A second example of an ongoing project concerning student involvement in EXL is the Invention Evaluation Service IES at the University of the Pacific. Started in 1999, the IES utilizes new product development evaluation models that might not be available to the average new business or nascent business (Weick, 2003). While this program is limited to new inventions, products, or processes intended for strictly commercial use, the basic concept and approach could be applicable to both for or not-for profit ventures. Under the direction of faculty members from the Eberhardt School of Business, graduate research assistants evaluate new inventions based on a new product development model derived from one designed by Cooper and Kleinschmidt (1986). The model is thorough, providing information for the inventors on everything from an initial screening to market launch. This approach could easily be adapted to university innovations, involving both graduate and undergraduate students through EXL programs that would be appropriate for each depending on their level of competence.

\section{A NEW MODEL}

Social entrepreneurs with institutional support stand a better chance of succeeding in the external environment, at least in the short run. This paper proposes that university innovation can be facilitated through student experiential learning, such as the SBI field consulting project, engaging students in the preparation of feasibility studies, business plans, or business consulting, providing a link between the academic institution and the marketplace. This added step in technology transfer has the potential to accomplish several things. About $75 \%$ of university inventions or creations are never brought to market for a variety of reasons. Having direct student involvement provides an inexpensive method to analyze the potential of a new invention or perform additional development of the concept to demonstrate market viability and consumer acceptance. In addition, the students obtain invaluable experience. The link to social entrepreneurship is made when worthwhile innovations that help ameliorate societal ills can be given a thorough vetting period by a cross functional student team versed in not only business but other fields.

With the support of the inventors, university technology transfer offices, social entrepreneurs, and university departments, a vast quantity of resources can be productively directed at nascent projects. As such, universities will have the opportunity to increase the yield on their intellectual property investments, students will gain valuable learning experiences, and society will have the opportunity to benefit from these inventions. The New Model in Figure 1 shows the system for the key stakeholders to cooperate and illustrates the path for social entrepreneurs to act as the bridge from the University to commercial and governmental enterprises. While a social entrepreneur may develop and commercialize the product on his/her own, the possibility still exists that they may sell or license it to an existing corporation or they could work with a government entity to get the product of service to market. 


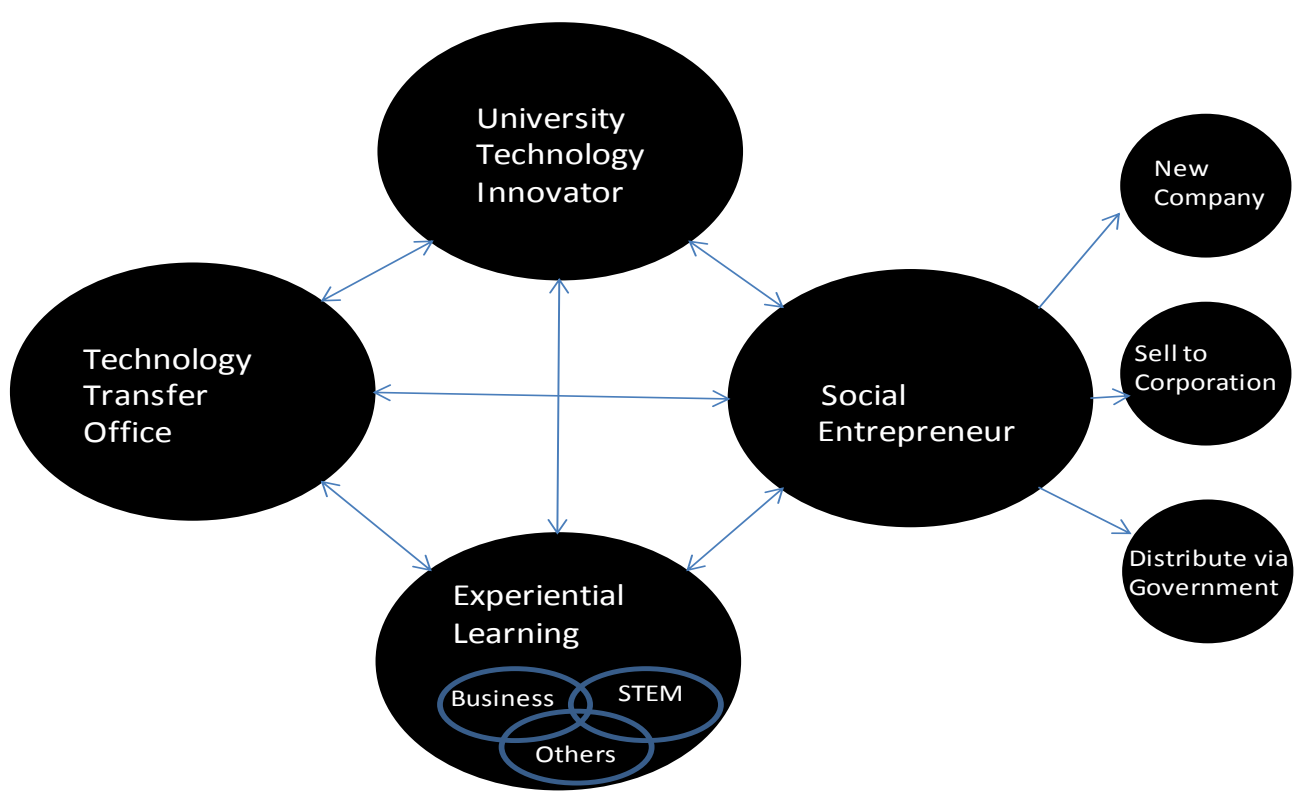

Figure 1. The New Model

\section{IMPLICATIONS}

The adoption of this model will enable university technology transfer offices to further develop intellectual properties in their patent portfolio or allow them to better market their portfolio. This approach incorporates the key tenants of SSM and will be achieved by developing experiential learning opportunities for students. Programs across the university will benefit as science, technology, engineering, and math (STEM) programs, the business school, and other departments like communications and the arts all have skills sets that can be tapped to increase the value of the patent portfolio. In return, students will learn valuable skills as they apply their lessons to real-world projects. Social entrepreneurs can also contribute their skills to assist with the development and have the potential to benefit as the technologies are advanced or their market potential is more clearly defined. When $75 \%$ of the average university patent portfolio goes unlicensed, there is ample opportunity to refine, further develop, and better market the existing assets. Universities will win by receiving more licensing revenue. Community stakeholders will win as market ready technologies yield new products and new companies, and the students will win via the skills and knowledge that they acquire from the experience. Social entrepreneurs bring an added dimension to the model as they will focus on technologies with the potential ameliorate societal ills. The advancement provided by the student groups will increase the potential of success for social entrepreneurs.

\section{AUTHOR INFORMATION}

Dr. John Lipinski is an Associate Professor of Management and Marketing at Middle Tennessee State University. He earned his doctorate from the University of Pittsburgh. Before turning to academia, Dr. Lipinski held managerial positions with companies such as Procter \& Gamble and Warner Lambert. His research covers a number of areas in Strategic Management and Marketing. E-mail: john.lipinski@mtsu.edu (Corresponding author) 
Dr. Donald L. Lester is a Professor of Management at Middle Tennessee State University. He earned his doctorate from the University of Memphis. His previous academic positions include Chair of the Center for Entrepreneurial and Family Business Studies at Arkansas State University and Dean of the McAfee School of Business at Union University. His research interests include business strategy, organizational life cycle, and small business entrepreneurship. Prior to his academic career, Dr. Lester owned and operated three small businesses. E-mail: don.lester@mtsu.edu

Dr. Jeananne Nicholls is an Associate Professor of Management at Slippery Rock University. She earned her doctorate from Kennesaw State University. Prior to her academic career she worked in the nonprofit sector to commercialize NASA- and other federally-developed technology through technology-based economic development initiatives. As a consultant, she worked with organizations to develop and operationalize strategic management and marketing plans. While working in the healthcare sector, she managed multimillion dollar collaborative research programs with the DoD. Her research interests include service leaning, strategic philanthropy, CSR, social entrepreneurship, and nonprofit management/marketing. E-mail: jeananne.nicholls@ sru.edu

\section{REFERENCES}

1. Alvord, S.H.B., Brown, D., and Letts, C. (2004). Social entrepreneurship and societal transformation: An exploratory study. The Journal of Behavioral Science, 40(3), 260-282.

2. Armstrong, S. \& Mahmud, A. (2008). Experiential learning and the acquisition of managerial tacit knowledge. Academy of Management Learning \& Education, 7(2).

3. Arnold, E., Brown, N., Eriksson, A., Jansson, T., Muscio, A., Nählinder, J., \& Zaman R., (2006). The Role of Industrial Research Institutes in the National Innovation System: A Report to VINNOVA, Technopolis, October.

4. Ashoka. (2006). Ashoka: Innovators for the public.

5. Association for Experiential Education (1994). AEE Definition of Experiential Education. Boulder, CO.; Association for Experiential Education.

6. Association of University Technology Managers (1996). AUTM Licensing Survey FY 1991 - FY 1995: A Five Year Survey Summary of Technology Licensing (and Related) Performance for U.S. and Canadian Academic and Nonprofit Institutions, and Patent Management Firms. Norwalk, CT.

7. Austin, J., Stevenson, H., and Wei-Skillern, J. (2006). Social and commercial entrepreneurship: Same, different or both? Entrepreneurship Theory and Practice, 30, 1-22.

8. Baum, J., \& Bird, B. (2010). The Successful Intelligence of High-Growth Entrepreneurs: Links to New Venture Growth. Organization Science, 21(2), 397-412.

9. Birch, D., Gundersen, J., Haggerty, A., \& Parsons, W. (1999). Corporate Demographics. Cambridge, MA: Cognetics, Inc.

10. Bloom, P.N., and Dees, J.G. (2008). Cultivate your ecosystem. Stanford Social Innovation Review, Winter 6(1), 47-53.

11. Bornstein, D. (2004). How to change the world: Social entrepreneurs and the power of new ideas. Oxford, UK: Oxford University Press.

12. Carraher, S.M., Buckley, M.R., \& Carraher, C.E. (2008). Research challenges in sustainable strategic management: Change and sustainability. International Journal of Sustainable Strategic Management, 1(1), $2-15$.

13. Chandler, D.L. (2012) We are all in this great enterprise together. MIT News. Retrieved from: http://web.mit.edu/newsoffice/2012/inauguration-ceremony-rafael-reif-0921.html, September 24, 2012

14. Chandler, G. \& Lyon, D. (2009). Involvement in knowledge-acquisition activities by venture team members and venture performance, Entrepreneurship Theory and Practice. 33(3) 571-592.

15. Chapman, S., McPhee, P., \& Proudman, B. (1995). What is experiential education? In K. Warren, M. Sakofs, \& J. S. Hunt, Jr. (Eds.), The theory of experiential education (pp. 235-247). Boulder, CO: Association for Experiential Education.

16. Clark, A., L. Labuzetta, J.N., Lawrence, B., Sahakian, S., \& Vyakarnum (2008). The Innovative Brain. Nature, 456, 168-169. 
17. Cohen, W., Florida, R., Randazzese, L, \& Walsh, J. (1998). "Industry and the academy: uneasy partners in the cause of technological advance." In Challenges to the Research University, edited by R. Noll.

Washington, D.C: Brookings Institution.

18. Cook, R., and Belliveau, P. (2008). The experiential student team consulting process, $3^{\text {rd }}$ edition. Mason, $\mathrm{OH}$ : Cengage Learning.

19. Cooper, R.G., \& Kleinschmidt, E.J. (1986). An investigation into the new product process: Steps, deficiencies, and impact. Journal of Product Innovation Management, 3(2), 71-85.

20. Dane, E. (2010). Reconsidering the trade-off between expertise and flexibility: A cognitive entrenchment perspective. Academy of Management Review, 35(4), 579-603.

21. Dart, R. (2004). Being "business-like" in a nonprofit organization: A grounded and inductive typology. Nonprofit and Voluntary Sector Quarterly, 33(2), 290-310.

22. Dees, J.G. (1998). Enterprising nonprofits. Harvard Business Review, 76, 55-67.

23. Dees, J.G., Emerson, J., \& Economy, P. (2001). Enterprising nonprofits: A toolkit for social entrepreneurs. New York, NY: John Wiley \& Sons.

24. Dees, J.G., and Anderson, B. (2003). Sector-bending: Blurring lines between nonprofit and for-profit. Society, 40(4), 16-27.

25. Dewey, J. (1916). Democracy and Education. New York. Macmillan.

26. Dewey, J (1938). Experience and Education. New York. Macmillan.

27. Eckhardt, J. T., and Sane, S. A. (2003). Opportunities and entrepreneurship. Journal of Management, 29, 333-349.

28. Etzkowitz, H., Webster, A., \& Healey, P. (Eds.) (1998). Capitalizing knowledge: New intersections of industry and academia. Albany, NY: State of New York Press.

29. Florida, R., \& Cohen, W. M. (1999). Engine or infrastructure? The university role in economic development. In W. During, R. Oakey, \& S. Kauser (Eds.), New technology based companies in the new millennium. New York: Pergamon.

30. Fujisue, K., (1998). Promotion of academia-industry cooperation in Japan — establishing the "law of promoting technology transfer from university to industry” in Japan. Technovation. 18, 6-7, 371-381

31. Furman, J. L., Porter, M.E., \& Stern, S. (2002). The determinants of national innovative capacity. Research Policy, 31, 899-935.

32. Galpin, T.J., and Bell, R.G. (2010). Social entrepreneurship and the L3C structure: Building the gap between non-profit and for-profit ventures. Journal of Business and Entrepreneurship, 22(2), 29-39.

33. Gemmell, R.M. (2011). Entrepreneurial innovation as a learning system. Doctoral Dissertation, Case Western University.

34. Gemmell, R. M., Boland, R.J., \& Kolb, D. (2011). The socio-cognitive dynamics of entrepreneurial ideation. Entrepreneurship Theory and Practice, 33(3), 1053-1073.

35. Gulbrandsen, M., \& Smeby, Jens-Christian, (2005). Industry funding and university professors' research performance. Research Policy, 34(6), 932-950.

36. Hibbert, S.A., Hogg, G., and Quinn, T. (2005). Social entrepreneurship: Understanding consumer motives for buying the big issue. Journal of Consumer Behavior, 4, 159-172.

37. Holcomb, T., R. Ireland, et al. (2009). Architecture of entrepreneurial learning: Exploring the link among heuristics, knowledge, and action. Entrepreneurship Theory and Practice, 33(1), 167-192.

38. Itin, C. M. (1999). Reasserting the philosophy of experiential education as a vehicle for change in the $21 \mathrm{st}$ Century." The Journal of Experiential Education, 22(2), 91-98.

39. Itin, C.M. (1997). The Orientation of social work faculty to the philosophy of experiential education in the classroom. Doctoral Dissertation, University of Denver.

40. Kato, K., \& Stevens, A.J. (2012). Technology Transfer's Twenty Five Percent Rule. Unpublished white paper.

41. Kolb, A. Y., \& Kolb, D. A. (2005). Learning styles and learning spaces: Enhancing experiential learning in higher education. Academy of Management Learning \& Education, 4(2), 193-212.

42. Kolb, D.A., (1984). Experiential Learning: Experience as the Source of Learning and Development. Prentice-Hall, Englewood Cliffs, N.J.

43. Kuratko, D.F., \& Hodgetts, R.M. (2001). Entrepreneurship: A Contemporary Approach, $5^{\text {th }}$ Ed. Fort Worth, TX: Dryden Press. 
44. Lawrence, A. (2008). Farming pharmaceuticals: Ventria Bioscience and the controversy over plant-made medicines. Case study presented at the annual meeting of the North American Case Research Association.

45. Leberman, L., (1994). A comparative analysis of civilian technology strategies among some nations. Policy Studies Journal, 22(2), 279-295

46. Licht, G. \& E. Nerlinger, (1998). New technology-based firms in Germany: A survey of the recent evidence. Research Policy. 26(9), 1005-1022

47. Light, P. (2005). Searching for social entrepreneurs: Who might they be, where they might be found, and what they do. Paper presented at the Association for Research on Nonprofit and Voluntary Associations.

48. Lipinski, J., Minutolo, M.C., \& Crothers, L.M., (2008). The complex relationship driving technology transfer: The potential opportunities missed by universities. Proceedings of the Institute of Behavioral and Applied Management, pp. 112-133.

49. Mair, J., \& Marti, I. (20006). Social entrepreneurship research: A source of explanation, prediction, and delight. Journal of World Business, 41, 36-44.

50. Mowery, D. C., Nelson, R.R., Sampat, B.N., \& Ziedonis, A.A. (2004). Ivory Tower and Industrial Innovation. University-Industry Technology Transfer Before and After the Bayh-Dole Act. Stanford University Press: Palo Alto, CA.

51. Niosi, J., \& Banik, M. (2005). The evolution and performance of biotechnology regional systems of innovation. Cambridge Journal of Economics, 29, 343-357.

52. Parnell, J. A. (2008). Sustainable strategic management: construct, parameters, research Directions. International Journal of Sustainable Strategic Management, 1(1), 35-45.

53. Peredo, A.M., \& McClean, M. (2006). Social entrepreneurship: A critical review of the concept. Journal of World Business, 41, 56-65.

54. Perlow, L.A., Okhuysen, G.A., \& Repenning, N.P. (2002). The speed trap: Exploring the relationship between decision making and temporal context. Academy of Management Journal, 45(5) 931-955.

55. Phan, P. H., \& Siegel, D. S. (2006). Lessons learned from quantitative and qualitative research in the U.S. and the U.K. (pp. 64): Rensselaer Polytechnic Institute. Working Paper available on-line: http://www.rpi.edu/dept/economics/www/workingpapers/

56. Pinard, M., \& Allio, R. (2005). Improving the creativity of MBA students. Strategy \& Leadership, 33(1), 49-51.

57. Politis, D. (2005). The process of entrepreneurial learning: A conceptual framework. Entrepreneurship Theory and Practice, 29(4), 399-424.

58. Porter, M. E. (2003). The economic performance of regions. Regional Studies, 37, 545-547.

59. Porter, M. E., \& Stern, S. (2001). Innovation: Location matters. MIT Sloan Management Review, $42,28-36$.

60. Prahalad, C. K., \& Hammond, A. (2002). Serving the World's Poor, Profitably. Harvard Business Review, 80(9), 48-58.

61. Roberts, D., and Woods, C. (2005). Changing the world on a shoestring: The concept of social entrepreneurship. University of Auckland Business Review, 7(1), 45-51.

62. Roessner, J.D., (2001). Technology transfer. In: Hill, C. Ed.., Science and Technology Policy in the US, A Time of Change. Longman, London.

63. Spiro, R. J., Collins, B. P., Thota, J. J., \& Feltovich, P. J. (2003). Cognitive flexibility theory: Hypermedia for complex learning, adaptive knowledge application, and experience acceleration. Educational Technology, 44, 5-10.

64. Stead, J. G., \& Stead, W. E. (2008). Sustainable strategic management: an evolutionary perspective. International Journal of Sustainable Strategic Management, 1(1), 62-81.

65. Steiner, GA. (1979) Strategic Planning: What every manager must know. New York. The Free Press.

66. Sullivan Mort, G., Weerawardena, J., and Carnegie, K. (2003). Social entrepreneurship: Toward Conceptualization. International Journal of Non Profit and Voluntary Sector Marketing, 8(1), 76-88.

67. Varga, A. (2000). Local academic knowledge transfers and the concentration of economic activity. Journal of Regional Science, 40, 289-309.

68. Vega, G., and Kidwell, R.E. (2007). Toward a typology of new venture creators: Similarities and contrasts between business and social entrepreneurs. New England Journal of Entrepreneurship, 10(2), 15-28.

69. Weick, C.W. (2003). A university-based model for evaluating inventions. International Journal of Entrepreneurship and Innovation, 4(4), 225-235. 